\title{
The Use and Abuse of University Discipline
}

\author{
Mark Mercer
}

Well-known recent cases of professors being disciplined by their universities include Rima Azar, ${ }^{1}$ David Porter, ${ }^{2}$ Derek Pyne ${ }^{3}$ and Amy Wax. ${ }^{4}$ Each case merits its own discussion, but in this paper, I will try to answer an abstract or theoretical question: what should discipline be used to do and what shouldn't it be used to do?

I will argue that the only proper goal a university could have in seeking to discipline a professor is to put an end to that professor's bad behavior-and only after informal means have failed. If my argument succeeds, discipline should not be used to right a wrong, give a miscreant what he deserves or correct anyone's thinking. Discipline should not be used to restore or reconcile, to mollify an aggrieved party, to signal the university's care and concern, or to deter others.

Penalties imposed by a university following disciplinary procedures include letters of warning, letters of reprimand, removal from classes, courses or programs, suspensions with pay, suspensions without pay, and, finally, termination for cause. I will argue that penalties should be applied only after a professor has been found, through a fair procedure, to have breached a sound

1 In May 2021, Rima Azar was suspended by Mount Allison University from June to December of that year for having posted opinions on her blog. The Society for Academic Freedom and Scholarship has collected documents about the case.

2 David B. Porter was fired by Berea College in 2019 for "professional misconduct" after distributing a survey on academic freedom and Title IX. The National Association of Scholars has sent to the president of Berea a letter in support of Porter: https://www.nas.org/blogs/article/an-open-letter-to-lyle-d-roelofspresident-of-berea-college.

3 Derek Pyne was suspended from Thompson Rivers University for a year after tagging a few colleagues on Facebook to alert them to an article about his earlier run-in with discipline. The Society for Academic Freedom and Scholarship has collected documents about the case.

4 In 2017, University of Pennsylvania Professor of Law Amy Wax was made ineligible to teach first-year students after commenting about achievement gaps within past first-year cohorts. The National Association of Scholars has written in defense of Prof. Wax: https://www.nas.org/blogs/article/in-defense-of-amywax.

Mark Mercer is a professor of philosophy at Saint Mary's University, in Halifax, Nova Scotia, and the president of the Society for Academic Freedom and Scholarship; sergechestnut@gmail.com. The author thanks Rima Azar, Janice Fiamengo, Patrick Keeney, Kathleen Lowrey, Dave Porter, Kenneth Westhues and Frances Widdowson for critical discussion of an earlier draft. Mercer last appeared in $A Q$ in summer 2021 with "Self-Censorship and the Academic Mission." 
university regulation. Penalties should be only as severe as required to prevent the professor from behaving badly (in the same way) again. Professors found to have breached a regulation should be terminated only for a second or third violation and only if termination is necessary to ensure that the university can again function as it should - so that students get taught and research progresses.

Disciplinary procedures, we must be clear, aim neither at raising a professor's standard of teaching or research nor at addressing the personal gripes that can keep professors and other members of the campus community from enjoying university life. Disciplinary procedures, then, are to be distinguished from both quality review and conflict resolution. One abuse of disciplinary procedures, then, is to use them to investigate a professor's academic performance; ${ }^{5}$ another is to use them to force a professor to get along with a colleague, student, or staff member. In addition to disciplinary procedures, universities should have procedures or traditions concerned specifically with bringing underperforming professors up to standard and maintaining a pleasant social environment.

Many of the regulations to which appeals to disciplinary procedures can be appropriate fall into categories we might call schedule and corruption. A professor who is frequently late to class or absent during office hours, or who never distributes the grading scheme on time, or who smokes, drinks, views pornography or keeps pets in his office (when doing so is contractually forbidden), or who exceeds the hours for which he may accept pay from outside sources, or who pilfers stamps or accepts bribes, or who plagiarizes or fabricates data, or publishes a student's work as his own, or who lists publications that appeared in pay-for-play venues as peer-reviewed, may be called to discipline. He's been talked to about his bad behavior, but he digs in his heels. It's no good that his students or colleagues have to live with his ways, so it's time to address the problem formally. Perhaps imposing a penalty on him will change things. If it doesn't, he can be directed to pack his bags.

Along with schedule and corruption, there's another category of regulation under which a summons to discipline can be appropriate: harassment. But that category, as university administrators and others now conceive it, puts pressure on my stipulation in this paper that the regulations allegedly infringed

$5 \quad$ Acadia University psychology professor Rick Mehta's teaching was disparaged throughout the disciplinary procedure against him, presumably to make firing him more palatable. The Society for Academic Freedom and Scholarship has collected documents about the case. 
are academically sound. Until yesterday, "harassment" meant harassment. Nowadays, for many people, the concept of harassment covers behavior that annoys, offends or upsets some people, behavior properly dealt with through conflict resolution or simply tolerated. The expanding reach of the concept of harassment has not been good for universities or for their ethos of freedom and individuality. Indeed, actual harassment does occur and can do great damage. A professor who is frequently intentionally hostile to another professor or to students or staff or who sets out to make someone miserable needs to be dealt with should talking to him fail. So, too, do those who offer quid pro quo arrangements.

My contention, again, is that discipline should be used only to stop a professor from misbehaving with regard to a sound university regulation. I suspect all agree that discipline can properly be used to this end. What might be controversial, then, is my claim that that's all it can properly be used for. I deny, for one, that disciplinary procedures or penalties should ever be used retributively. A penalty imposed as discipline should not be used as punishment for wrongdoing; university officials should not intend to impose pain or hardship on the offender to balance the books. Punishment as retribution is appropriate-indeed, required-when a law has been broken and people or animals harmed (or put at risk of harm). But only a properly constituted justice system is competent to mete out retribution justly. Otherwise, what results is vengeance. University regulations are not laws, and no university system of discipline is a properly constituted system of justice (for one, universities are not democracies or marked by consent of the governed). It can be no business of a university, then, to see that transgressors of university regulations (or any transgressors at all) pay a price. Discipline might require penalties, but universities should be clear that the penalties they impose are not instances of retributive punishment.

Retribution must be left to the state, and that's one reason universities should not aim at punishment through discipline. Another reason follows specifically from what a university is. If a university is to be a place of intellectual community, professors must value the intellectual and moral autonomy of their fellows. Respect for the intellectual and moral autonomy of others requires that we don't act in the spirit of retribution, that we don't try to punish people, even when we are forced to impose penalties on them. We respect autonomy when we give reasons or create conditions that influence behavior, but not when we inflict hardship intending thereby to hurt or harm. 
A person committed to treating others as intellectually and morally autonomous agents, I said, will not seek to create hardship for the sake of retribution. Whether one has that commitment or not is another matter (there are reasons for and against adopting such a commitment), though without it one cannot engage in liberal study for its own sake. So, for those within the spirit of liberal study, penalties imposed for breaching university regulations are not to be conceived as giving the miscreant the punishment he deserves for his transgression. At a university that values liberal study, penalties are simply part of a system of necessary or useful incentives to keep the institution functioning to serve its ends.

Retribution is not the only abuse of discipline. Sometimes disciplinary penalties are used to impose restitution or forge reconciliation and not, or not only, to set a rule-breaker straight. Imposing restitution or reconciliation through discipline is an abuse of the process for involvement in discipline is involuntary, and its results are binding. Restitution and reconciliation have to come of their own if they are to be consistent with respect for autonomy. If I've been forced to say “I'm sorry,” I haven't actually apologized, no matter how sincere my contrition. ("Forced apology" is an oxymoron.) Demanding that I apologize makes it impossible for me to do so even if I want to.

Restitution and reconciliation aside, summoning a professor to discipline can be an effective way to placate or mollify an offended, hurt, or wronged person. Certainly, a university might have strong reason to want to appease an aggrieved party, especially if he is powerful or threatening. And yet, universities should not use discipline to mollify a ruffled complainant. A university that uses discipline to placate someone treats the accused professor with contempt. It is using him independently of his will to serve another.

Further, discipline should not be used to rehabilitate the erring professor, at least not in the sense in which "rehabilitation" implies correcting the professor's beliefs or values. The professor must be left free to continue to believe and value what he wants; that's not the university's business. Indeed, seeking to change someone's beliefs or values by pressures other than those of argument or evidence is contrary to academic values, as well as contemptuous. Penalties and threats of penalties are not arguments. The university's only proper interest here is that the professor doesn't continue to breach the regulation, not that he comes to understand and accept the university's account of why professors shouldn't breach it. 
Finally, discipline certainly shouldn't be used by a university to signal its commitment to a social goal, to antiracism, for instance, or to a diversity, inclusion, or equity initiative. Nor should discipline be used to deter other would-be miscreants.

I suspect-although, because the information is lacking, I do not know-that universities regularly initiate disciplinary procedures and impose penalties wrongly. I suspect, that is, that if we were able to look, we would find that universities, at least in North America, have often used discipline (to try) to punish, to restore, to reconcile, to placate the offended, to rehabilitate the offender, to warn off others, and to demonstrate which or whose side they are on. My suspicions are based on the particular cases I've learned about through my involvement with the Society for Academic Freedom and Scholarship. Of course, that's not a fair sample and might represent exceptions to the rule.

Universities are not democratic polities, and so they cannot dispense justice. It is presumptuous of them to imagine they could. The closest they can come is vengeance. Since retribution, restitution, and rehabilitation fall within the purview of justice (for my part, though, I think attempting rehabilitation is always to act unjustly), universities are incompetent to seek them. Universities, of course, must strive to be just institutions; they are just simply when they are open, fair, and responsible to their (properly constituted) policies and regulations. Since it would be unjust for a university to try to render substantive justice, a university must not use disciplinary procedures as though they could result in justice.

Placation or mollification, reconciliation, commitment signalling and deterrence are the other ends I've said I suspect universities often aim at when they call professors on the carpet. Each of these ends could, in some circumstances, be worth securing. But even when discipline could serve one of them, it would, I have argued, be disrespectful and anti-academic for a university to turn to discipline, although the intended goal is laudable.

On my preferred conception, universities are places at which people who value intellectual and moral autonomy come together in community to investigate the things of the world. Because they value intellectual and moral autonomy, university people favor open, free and critical discussion. They want the members of their community to be candid and direct and they want their relations with their fellows to be sincere and personable. But complaints that initiate discipline for harassment, even for actual harassment and not merely 
annoyance, hurt, or offense, set up a third party between community members. They summon an authority who rules on the quality of one member's treatment of another. Creating authorities to stand between people introduces indirection, insincerity, and dishonesty into a university community.

Universities honor academic values and serve academic ends best by leaving their civil communities alone as far as possible and letting the professors and students themselves figure out how to accommodate and live with each other. Universities need to be very careful not to create rules that govern personal relations among university members. It is for this reason that expanded conceptions of harassment, including policies against hostile environments, are threatening to university life. Safe-and-respectful campus policies and codes of behavior are extremely dangerous, for they encourage members of the campus community to file complaints simply when they don't like how others go about their academic or personal business. These policies thereby contract the area in which university people may exercise their autonomy. They impose pressures on belief, value, and comportment other than those of argument and example.

My point is that disciplinary procedures are always anti-collegial, even when they are warranted. They are hierarchical, setting administrators above professors in power. Whatever might be said at a disciplinary meeting, it is not said as part of a critical discussion, for some present at such meetings speak as officials, and others have to be careful what they say, or else. Discipline threatens the campus ethos of free and equal people gathering to investigate the world. For that reason, disciplinary proceedings must be limited to breaches of clear regulations and initiated only after informal attempts to curb bad behavior have failed. Administrators have a profound obligation to try to find solutions before seeking to impose penalties. An administrator who summons a professor to a disciplinary meeting without talking with him about the matter has betrayed university values.

But after collegial means, such as discussion, have failed, a summons might be in order. For a university even to begin disciplinary procedures, the professor's behavior must, of course, have been judged by a senior academic administrator not only to have breached a regulation but to be harmful to the university's ability to function well as an institution of intellectual community, the members of which are engaged in learning, teaching, researching, and caring for the institution. Being summoned deprives a professor of time and energy that should go to his work and can sour him on his institution. The good 
to be attained through going the disciplinary route must be weighed against the harm to collegiality and the offence against academic values that discipline entails. The professor's behavior has been injurious to the institution and, if he continues with it, more injury will follow. Talking with the professor hasn't worked and tolerating his behavior is not an option.

Once senior administrators decide to allege that the professor has breached a university regulation, disciplinary procedures must move quickly. A constant threat is that the process itself becomes punishment. Administrators can meet that threat only through conscientiousness and a commitment to natural justice.

An objection to my ideas is that many of the distinctions I've drawn are artificial or unworkable. Penalties, I have said, should not be imposed in the spirit of retribution. But to impose a penalty is always to seek retribution. Or, since the spirit in which an administrator seeks to impose a penalty cannot be observed, we have no means of telling whether the penalty is retributive rather than merely an incentive. I have also said that professors should not be summoned to discipline in order to make complainants whole again or to placate them. But a student who complains that a professor plagiarized or stole his work, for instance, is certainly made whole when a disciplinary investigation publicly acknowledges that the work is his.

Well, not all penalties are punishments-for-the-sake-of-punishment. Retribution is no part of sending a player to the penalty box or awarding a team a penalty shot. Speeding tickets are not hardships that balance the moral books. Second, intentions are not entirely unreadable. Words spoken or written by administrators involved in a disciplinary procedure can provide sound evidence of what the administrators mean to accomplish. Finally, that an outcome can be anticipated and lauded does not imply that that outcome was the motive or goal of the process. That the investigation showed the student to be the work's originator can be a by-product of a procedure intended only to reveal what the professor did.

Again, if an institution is one of liberal study, those committed to that institution will seek to minimize all pressures on belief and values save those of evidence and argument. For that reason, even as they do what they can to support inquiry, interpretation, and learning, they will not use university procedures to seek retribution, restitution, reconciliation, placation, or rehabilitation, and they won't use means such as discipline to signal commitments or to scare 
would-be miscreants. Doing so would be to show disrespect for the intellectual and moral autonomy of the members of the university community.

The point and nature of disciplinary procedures against professors and the penalties imposed in the name of discipline are woefully under-discussed, both in the literature about the care of the university and in the universities themselves. (So, also, is university discipline against students.) University discipline needs to be talked about critically and its virtues and vices understood. Today, this is especially important, for recourse to discipline is both symptom and cause of our universities' abandonment of academic values and liberal study. As universities continue to move away from their academic mission and toward being instruments for social-justice causes, discipline is sure to be subject to even more frequent and extreme abuse. 